\title{
Amycolatopsis albidoflavus sp. nov.
}

\author{
Soon Dong Lee ${ }^{1,2}$ and Yung Chil Hah ${ }^{1}$
}
1 School of Biological Sciences and Research Center for Molecular Microbiology, Seoul National University, Seoul 151-742, Republic of Korea
2 Department of Plant Pathology, University of Minnesota, St Paul, MN 55108, USA

\author{
Author for correspondence: Yung Chil Hah. Tel: +82 2880 6700. Fax: +82 28884911 \\ e-mail: hahyungc@snu.ac.kr
}

\begin{abstract}
The generic position of an actinomycete strain, 'Pseudonocardia sp.' IMSNU 22139, was investigated by the phylogenetic analysis of $16 \mathrm{~S}$ rDNA sequence. Comparative studies of 165 rDNA sequences indicated that this organism consistently formed a distinct clade within the radiation of the genus Amycolatopsis of the family Pseudonocardiaceae. This organism was also found to have chemotaxonomic properties consistent with those of the genus Amycolatopsis, which were represented by a type IV cell wall (mesodiaminopimelic acid, arabinose and galactose), a major menaquinone of MK-9( $\left.\mathrm{H}_{4}\right)$, a predominant fatty acid of 14-methylpentadecanoic acid, phosphatidylmethylethanolamine as a diagnostic phospholipid (a phospholipid type PII pattern) and DNA base composition of $68.5 \mathrm{~mol} \% \mathrm{G}+\mathrm{C}$. On the basis of physiological properties, cellular fatty acid profiles and its unique phylogenetic position, this organism is readily differentiated from all of the validly described species of the genus Amycolatopsis, and the name Amycolatopsis albidoflavus sp. nov. is proposed for it. The type strain is IMSNU $22139^{\top}$ ( = KCTC 9471' $=$ ATCC 53205').
\end{abstract}

Keywords: Amycolatopsis albidoflavus sp. nov., actinomycetes, 16S rDNA sequence studies

\section{INTRODUCTION}

The genus Amycolatopsis was proposed by Lechevalier et al. (1986) for amycolate, nocardioform actinomycetes having a phospholipid type PII pattern (phosphatidylethanolamine as a diagnostic phospholipid) among strains that were previously described as members of the genus Nocardia, and currently contains 10 validated species, Amycolatopsis alba, Amycolatopsis azurea, Amycolatopsis coloradensis, Amycolatopsis fastidiosa, Amycolatopsis japonica, Amycolatopsis mediterranei, Amycolatopsis methanolica, Amycolatopsis orientalis (with Amycolatopsis orientalis subsp. lurida), Amycolatopsis sulphurea and Amycolatopsis thermoflava (Lechevalier et al., 1986; Henssen et al., 1987; de Boer et al., 1990; Mertz \& Yao, 1993; Labeda, 1995; Goodfellow et al., 1997; Chun et al., 1999).

Members of the genus Amycolatopsis, which produce branched, fragmenting aerial and substrate mycelia,

The EMBL accession numbers for the 16S rDNA sequences of Amycolatopsis methanolica IMSNU 20055', Amycolatopsis azurea IMSNU 20053', Amycolatopsis fastidiosa IMSNU 20054 ${ }^{\top}$ and Amycolatopsis orientalis IMSNU 20058 reported in this paper are AJ249135, AJ400709, AJ400710 and AJ400711, respectively. are characterized by the following cell chemistry: a type IV cell wall (meso-diaminopimelic acid, arabinose and galactose in the cell wall) (Lechevalier et al., 1986); muramic acid in an $N$-acetyl form (Henssen et al., 1987); phosphatidylethanolamine as a diagnostic phospholipid (a phospholipid type PII pattern according to the classification of Lechevalier et al., 1977); the absence of mycolic acids (Lechevalier et al., 1986); a major menaquinone of MK-9 $\left(\mathrm{H}_{4}\right)$ with a minor amount of MK-9 $\left(\mathrm{H}_{2}\right)$ (Lechevalier et al., 1986; Yassin et al., 1993); and complex mixtures of saturated and branched-chain fatty acids (Henssen et al., 1987; Mertz \& Yao, 1993). Phylogenetically, this genus forms a monophyletic clade within the radius of the family Pseudonocardiaceae (Warwick et al., 1994; Kim \& Goodfellow, 1999). 'Amycolatopsis rugosa', which was originally described as a member of the genus Amycolatopsis, was transferred to the new genus Prauserella on the basis of 16S rDNA sequence studies and chemotaxonomic characterization (Kim \& Goodfellow, 1999).

While investigating the phylogenetic relationship of Pseudonocardia strains, we found that 'Pseudonocardia sp.' IMSNU 22139 was related to members of the genus Amycolatopsis (Lee et al., 2000b). In this paper, 
we describe the characterization and classification of 'Pseudonocardia sp.' IMSNU 22139, for which the new species of the genus Amycolatopsis, Amycolatopsis albidoflavus sp. nov., is proposed.

\section{METHODS}

Micro-organisms and culture conditions. Strain IMSNU 22139 was cultivated on Trypticase Soy Broth (Difco) for $3 \mathrm{~d}$ at $30{ }^{\circ} \mathrm{C}$ with shaking. After the purity was checked, the cells were harvested by centrifugation and washed twice with distilled water. For phenotypic and genotypic comparison, the following reference strains were used: Amycolatopsis alba IFO $15602^{\mathrm{T}}$ ( = IMSNU 22095 $\mathrm{I}$ ), Amycolatopsis azurea IFO $14573^{\mathrm{T}}$ ( = IMSNU 20053 $)$, Amycolatopsis coloradensis IFO $15804^{\mathrm{T}}\left(=\right.$ IMSNU $\left.22096^{\mathrm{T}}\right)$, Amycolatopsis fastidiosa IFO $14105^{\mathrm{T}} \quad\left(=\right.$ IMSNU $\left.20054^{\mathrm{T}}\right)$, Amycolatopsis mediterranei IFO $13142^{\mathrm{T}}$ (= IMSNU 20056 ${ }^{\mathrm{T}}$ ), Amycolatopsis methanolica IFO $15065^{\mathrm{T}} \quad\left(=\mathrm{IMSNU} 20055^{\mathrm{T}}\right)$, Amycolatopsis orientalis IFO $12806^{\mathrm{T}}$ (= IMSNU 20058 ${ }^{\mathrm{T}}$ ) and Amycolatopsis sulphurea IFO $13270^{\mathrm{T}} \quad(=\mathrm{IMSNU}$ $\left.20060^{\mathrm{T}}\right)$

Morphological and physiological characteristics. Acid production from carbohydrates was determined by using Bacto OF basal medium (Difco) including each filter-sterilized compound at a final concentration of $1 \%$. Decomposition of adenine, hypoxanthine, DL-tyrosine and xanthine was examined as described previously (Gordon et al., 1974). Oxidase activity was determined by monitoring the oxidation of tetramethyl- $p$-phenylenediamine on a filter paper disc. Catalase activity was determined with a $3 \%(\mathrm{v} / \mathrm{v})$ hydrogen peroxide solution. The temperature for growth was tested at $10,30,37$ and $45^{\circ} \mathrm{C}$. The production of hydrogen sulfide was detected on Trypticase Soy Broth (Difco) by using lead acetate strips. Urease activity was determined by a colour change in Bacto urea broth (Difco). Nitrate reduction, decomposition of hippurate and hydrolysis of casein, gelatin and starch were examined by using previously described methods (MacFaddin, 1980). $\mathrm{NaCl}$ tolerance was studied on nutrient agar containing $\mathrm{NaCl}$ at final concentrations of 2, 3, 5, 7 and $10 \%(\mathrm{w} / \mathrm{v})$. For scanning electron microscopy, strain IMSNU 22139 was grown on inorganic salts-starch agar (ISP medium 4) at $28^{\circ} \mathrm{C}$ for $14 \mathrm{~d}$. The agar blocks were cut from the growth medium, fixed with $1 \%$ osmium tetroxide, and dehydrated through a graded ethanol series, and the ethanol was replaced with isoamyl acetate. After critical point drying, the samples were sputter-coated with gold under a vacuum and observed by a model Stereoscan 260 scanning electron microscope (Cambridge).

Chemotaxonomy. The isomer of diaminopimelic acid was identified using the method of Staneck \& Roberts (1974). The sugar compositions of whole-cell walls were determined by GC as described by Saddler et al. (1991). The acyl type of the cell wall was analysed by using the method of Uchida \& Aida (1984). The presence of mycolic acids was determined by the method of Minnikin et al. (1980). Polar lipids were extracted by the small-scale method of Minnikin et al. (1984). The purified menaquinones were identified by HPLC (Kroppenstedt, 1985). The phospholipid composition was determined by a previously described method (Minnikin et al., 1977). Cellular fatty acid methyl esters were prepared by a previously described method (Minnikin, 1988) and analysed by GC with a Hewlett Packard model 5890A gas chromatograph as described previously (Lee et al., 2000c).
Determination of DNA base composition. Genomic DNA was extracted according to Hopwood et al. (1985). The $\mathrm{G}+\mathrm{C}$ content of the DNA was determined by HPLC (Mesbah et al., 1989).

Phylogenetic analyses. The PCR cloning and sequencing of 16S rDNA were carried out by using a model ALFexpress DNA sequencer (Pharmacia Biotech) and the Cy5 AutoRead Sequencing Kit (Pharmacia) as described previously (Lee et al., 2000a). Multiple alignment of the sequences determined in this study and reference sequences was performed by using the CLUSTAL W program (Thompson et al., 1994) and was manually optimized by comparison with Escherichia coli sequence (Brosius et al., 1978). Phylogenetic analyses were performed using the neighbour-joining (Saitou \& Nei, 1987) and maximum-parsimony (Fitch, 1972) methods. Evolutionary distances for the neighbour-joining method were computed by the method described by Jukes \& Cantor (1969). Parsimony analysis was performed with the PAUP program for the Macintosh (Swofford, 1998). The confidence level of tree topologies was evaluated by bootstrap analysis (Felsenstein, 1985) of the neighbour-joining data, using 1000 resamplings. The final tree was constructed using the neighbour-joining method, based on 1307 unambiguous nucleotides present in all strains.

\section{RESULTS AND DISCUSSION}

16S rDNA sequence studies showed that 'Pseudonocardia sp.' IMSNU 22139 was related to members of the genus Amycolatopsis of the family Pseudonocardiaceae (Lee et al., 2000b). The phylogenetic relationship is also supported by chemotaxonomic properties. Strain IMSNU 22139 was characterized by a type IV cell wall (meso-diaminopimelic acid, arabinose and galactose in whole-cell hydrolysates), a major menaquinone of MK-9 $\left(\mathrm{H}_{4}\right)$, muramic acid in an $\mathrm{N}$-acetylated form and a base composition of $68.5 \mathrm{~mol} \%$. Mycolic acids were absent. The fatty acid profiles contained a mixture of saturated, unsaturated, and branched-chain acids, iso-hexadecanoic acid being the predominant fatty acid. The polar lipid profiles contained considerable amounts of phosphatidylmethylethanolamine and phosphatidylinositol, along with trace amounts of phosphatidylethanolamine and diphosphatidylglycerol (a phospholipid type PII pattern; Lechevalier et al., 1977).

An almost complete $16 \mathrm{~S}$ rDNA sequence for the strain IMSNU 22139 obtained in our recent study (Lee et al., 2000b) comprises 1477 nucleotides ( $>98 \%$ of the $E$. coli sequence). To increase the quality of the reference sequences, almost complete $16 \mathrm{~S}$ rDNA sequences of the following strains were also determined in this study: A. azurea IMSNU 20053 ${ }^{\mathrm{T}}$, A. fastidiosa IMSNU $20054^{\mathrm{T}}, A$. methanolica IMSNU $20055^{\mathrm{T}}$ and A. orientalis IMSNU $20058^{\mathrm{T}}$. The newly determined sequences were compared with the corresponding sequences of the remaining validated species of the genus Amycolatopsis, and the representatives of the genera Pseudonocardia and Actinobispora. A total of 1307 unambiguous aligned positions present in all strains between 72 and 1452 (E. coli positions) were used for this analysis. Saccharothrix violacea (Lee et 


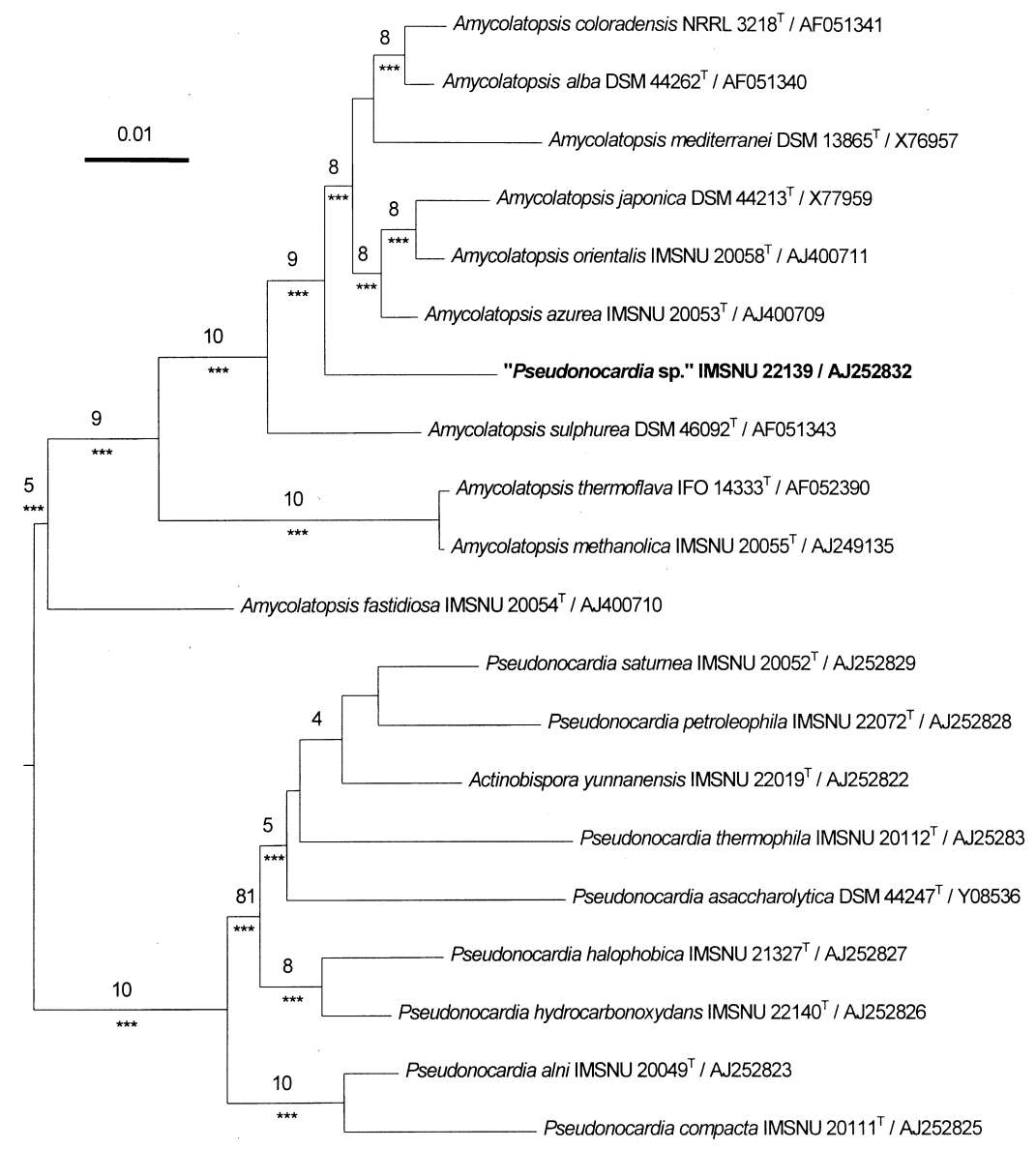

Fig. 1. Phylogenetic tree displaying the position of 'Pseudonocardia sp.' IMSNU 22139 with regard to related taxa. Triple asterisks indicate the branching nodes that were also recovered in the parsimony analysis. The numbers at the branching nodes are the percentages of occurrence in 1000 bootstrapped trees (only values greater than $40 \%$ were indicated). Scale bar indicates 1 substitution per 100 nucleotides.

al., 2000c) was used as an outgroup. The phylogenetic tree (Fig. 1) shows that strain IMSNU 22139 forms a distinct lineage within the radius of the genus Amycolatopsis, which was supported by a high bootstrap value of $98 \%$. Parsimony analysis based on the same data sets resulted in a tree showing similar topologies. The levels of $16 \mathrm{~S}$ rDNA sequence similarity between strain IMSNU 22139 and members of the validated species of the genus Amycolatopsis ranged from 93.7 to $97.4 \%$. Of the members of the genus Amycolatopsis, A. azurea $(97 \cdot 4 \%)$ and A. orientalis $(97 \cdot 4 \%)$ showed the highest sequence similarity to strain IMSNU 22139. Thus, phylogenetic clustering and chemotaxonomic characterization support strain IMSNU 22139 being a member of the genus Amycolatopsis.

The morphological study using a electron microscope showed that strain IMSNU 22139 had a typical characteristic of the genus Amycolatopsis (data not shown). Both aerial and vegetative hyphae were branched and fragmented. Other morphological features, such as sclerotia and sporangia, were not observed. All of the test strains including strain IMSNU 22139 produced acid from D-fructose and glycerol, but did not produce acid from D-melezitose, L-rhamnose and L-sorbose. Decomposition of casein, starch and DL-tyrosine was observed in all of the test strains. Table 1 shows physiological characteristics that differentiate strain IMSNU 22139 and the type species of the genus Amycolatopsis. A. azurea IMSNU $20053^{\mathrm{T}}$ in the degradation of starch and acid production from D-raffinose and sucrose, A. coloradensis IMSNU $22096^{\mathrm{T}}$ in $\mathrm{H}_{2} \mathrm{~S}$ production, $A$. fastidiosa IMSNU $20054^{\mathrm{T}}$ in the degradation of starch and gelatin, A. methanolica IMSNU $20055^{\mathrm{T}}$ in acid production from L-arabinose, D-galactose, L-rhamnose and D-trehalose and in the decomposition of urea and xanthine, $A$. orientalis IMSNU $20058^{\mathrm{T}}$ in nitrate reduction and in the degradation of xanthine, and $A$. sulphurea IMSNU $20060^{\mathrm{T}}$ in decomposition of casein and in acid production from maltose and glycerol showed different results from the previous study (de Boer et al., 1990; Labeda, 1995). On the basis of cellular fatty acid compositions (Table 2), strain IMSNU 22139 differs from the phylogenetic neighbours $A$. azurea and A. orientalis. The cell hydrolysates of strain IMSNU 22139 contained 14-methylpentadecanoic acid (i- $\mathrm{C}_{16: 0} ; 26 \cdot 1 \%$ ) as a predominant fatty acid. Considerable amounts of hexadecanoic acid $\left(\mathrm{C}_{16: 0} ; 10 \cdot 2 \%\right)$, 12-methyltridecanoic acid (i-C $\mathrm{C}_{14: 0}$; $9.8 \%)$, 13-methyltetradecanoic acid (i- $\left.\mathrm{C}_{15: 0} ; 8.7 \%\right)$, heptadecanoic acid $\left(\mathrm{C}_{17: 0} ; 7.8 \%\right)$ and octadecanoic acid $\left(\mathrm{C}_{18: 0} ; 6.2 \%\right)$ were also present in addition to an unknown fatty acid $(7 \cdot 8 \%)$. Strain IMSNU 22139 can also be differentiated from the representatives of other 
Table 1 Differential characteristics of strain IMSNU 22139 and the type species of the genus Amycolatopsis

+ , Positive; w, weak positive; - , negative; ND, not determined.

\begin{tabular}{|c|c|c|c|c|c|c|c|c|c|c|c|}
\hline Characteristic & $\begin{array}{l}\text { Strain } \\
\text { IMSNU } \\
22139\end{array}$ & $\begin{array}{l}\text { A. alba } \\
\text { IMSNU } \\
\text { 22095 }^{\mathrm{T}}\end{array}$ & $\begin{array}{c}\text { A. azurea } \\
\text { IMSNU } \\
20053^{\mathrm{T}}\end{array}$ & $\begin{array}{l}\text { A. coloradensis } \\
\text { IMSNU } \\
22096^{\mathrm{T}}\end{array}$ & $\begin{array}{c}\text { A. fastidiosa } \\
\text { IMSNU } \\
\text { 20054 }^{\mathrm{T}}\end{array}$ & $\begin{array}{c}\text { A. japonica } \\
\text { DSM } \\
\mathbf{4 4 2 1 3}^{\mathrm{T} *}\end{array}$ & $\begin{array}{l}\text { A. mediterranei } \\
\text { IMSNU } \\
2^{00056^{T}}\end{array}$ & $\begin{array}{l}\text { A. methanolica } \\
\text { IMSNU } \\
20055^{\mathrm{T}}\end{array}$ & $\begin{array}{l}\text { A. orientalis } \\
\text { IMSNU } \\
2^{20058}{ }^{\mathrm{T}}\end{array}$ & $\begin{array}{l}\text { A. sulphurea } \\
\text { IMSNU } \\
20060^{\mathrm{T}}\end{array}$ & $\begin{array}{c}\text { A. thermoflava } \\
\text { IFO } \\
14333^{3 *}\end{array}$ \\
\hline \multicolumn{12}{|l|}{ Acid produced from: } \\
\hline Adonitol & + & + & + & - & - & + & - & + & + & - & + \\
\hline L-Arabinose & + & + & + & - & - & + & + & - & + & - & + \\
\hline D-Cellobiose & + & + & + & + & - & + & + & + & + & - & + \\
\hline meso-Erythritol & + & + & + & - & - & + & - & - & + & - & - \\
\hline D-Galactose & + & + & - & - & - & + & + & - & - & + & + \\
\hline D-Glucose & - & - & - & - & - & ND & - & $\mathrm{w}$ & - & + & ND \\
\hline meso-Inositol & + & + & + & + & - & + & + & - & + & - & - \\
\hline D-Lactose & + & + & + & - & - & + & + & - & + & - & + \\
\hline Maltose & - & + & + & - & - & + & + & - & + & + & - \\
\hline D-Mannose & + & - & - & - & - & ND & - & + & - & + & ND \\
\hline D-Mannitol & w & + & + & + & - & + & + & - & + & + & + \\
\hline Melibiose & - & + & - & - & - & + & + & - & - & - & + \\
\hline $\begin{array}{l}\text { Methyl } \alpha \text {-D- } \\
\text { glucoside }\end{array}$ & - & + & + & + & - & + & - & - & + & - & + \\
\hline D-Raffinose & - & + & + & - & - & + & + & - & - & - & + \\
\hline Salicin & - & + & + & + & + & + & + & $\mathrm{w}$ & + & - & + \\
\hline D-Sorbitol & - & - & - & - & - & - & - & + & - & - & + \\
\hline Sucrose & + & - & + & - & + & + & + & - & + & - & - \\
\hline D-Trehalose & + & + & + & + & + & + & + & - & + & + & + \\
\hline D-Xylose & + & + & + & + & + & + & + & + & + & - & + \\
\hline D-Xylitol & - & - & - & - & - & ND & - & + & - & - & ND \\
\hline \multicolumn{12}{|l|}{ Enzyme activity: } \\
\hline Nitrate reductase & + & - & + & + & + & - & + & + & + & + & + \\
\hline $\mathrm{H}_{2} \mathrm{~S}$ production & + & + & + & - & - & + & + & + & + & + & ND \\
\hline \multicolumn{12}{|l|}{ Decomposition of: } \\
\hline Aesculin & + & + & + & + & + & + & + & + & + & - & + \\
\hline Gelatin & + & + & + & + & + & + & + & - & + & + & - \\
\hline Hypoxanthine & + & + & + & + & - & + & + & + & + & - & + \\
\hline Urea & w & + & + & - & - & - & - & + & + & - & + \\
\hline Xanthine & + & + & + & - & - & + & - & + & + & - & + \\
\hline \multicolumn{12}{|l|}{ Growth at: } \\
\hline & - & - & - & - & + & + & + & + & - & - & + \\
\hline $\begin{array}{l}\text { Growth on: } \\
7 \% \mathrm{NaCl}\end{array}$ & + & - & + & - & _- & + & w & - & - & - & - \\
\hline
\end{tabular}

* According to Goodfellow et al. (1997) and Chun et al. (1999).

Table 2 Cellular fatty acid compositions (\%) of strain IMSNU 22139 and the reference strains of the genus Amycolatopsis

\begin{tabular}{|c|c|c|c|}
\hline Fatty acid* & $\begin{array}{c}\text { Strain } \\
\text { IMSNU 22139† }\end{array}$ & $\begin{array}{c}\text { A. azurea } \\
\text { IMSNU } 20053^{\mathrm{T}}\end{array}$ & $\begin{array}{c}\text { A. orientalis } \\
\text { IMSNU 20058 }\end{array}$ \\
\hline 12-Methyltridecanoic acid $\left(\mathrm{i}-\mathrm{C}_{14: 0}\right)$ & $9 \cdot 8$ & & $4 \cdot 3$ \\
\hline Tetradecanoic acid $\left(\mathrm{C}_{14: 0}\right)$ & $1 \cdot 1$ & & \\
\hline 13-Methyltetradecanoic acid $\left(\mathrm{i}-\mathrm{C}_{15: 0}\right)$ & $8 \cdot 7$ & $29 \cdot 9$ & $15 \cdot 2$ \\
\hline 12-Methyltetradecanoic acid (ai- $\mathrm{C}_{15: 0}$ ) & & $3 \cdot 9$ & $1 \cdot 1$ \\
\hline Pentadecenoic acid $\left(\mathrm{C}_{15: 1}\right)$ & $2 \cdot 3$ & & $1 \cdot 3$ \\
\hline Pentadecanoic acid $\left(\mathrm{C}_{15: 0}\right)$ & $5 \cdot 8$ & $6 \cdot 5$ & $7 \cdot 2$ \\
\hline 14-Methylpentadecanoic acid (i- $\left.\mathrm{C}_{16: 0}\right)$ & $26 \cdot 1$ & $2 \cdot 9$ & $23 \cdot 8$ \\
\hline Hexadecenoic acid $\left(\mathrm{C}_{16: 1}\right)$ & $4 \cdot 0$ & $8 \cdot 8$ & $3 \cdot 5$ \\
\hline Hexadecanoic acid $\left(\mathrm{C}_{16: 0}\right)$ & $10 \cdot 2$ & $5 \cdot 7$ & $8 \cdot 6$ \\
\hline 15-Methylhexadecanoic acid (i- $\left.\mathrm{C}_{17: 0}\right)$ & $1 \cdot 6$ & $2 \cdot 6$ & $1 \cdot 5$ \\
\hline 14-Methylhexadecanoic acid (ai- $\mathrm{C}_{17: 0}$ ) & & $11 \cdot 8$ & $13 \cdot 7$ \\
\hline Heptadecenoic acid $\left(\mathrm{C}_{17: 1}\right)$ & $4 \cdot 4$ & & $1 \cdot 2$ \\
\hline Heptadecanoic acid $\left(\mathrm{C}_{17: 0}\right)$ & $7 \cdot 8$ & $25 \cdot 7$ & $12 \cdot 6$ \\
\hline 16-Methylheptadecenoic acid (i- $\left.\mathrm{C}_{18: 1}\right)$ & & & $1 \cdot 5$ \\
\hline Octadecanoic acid $\left(\mathrm{C}_{18: 0}\right)$ & $6 \cdot 2$ & $2 \cdot 1$ & $3 \cdot 0$ \\
\hline
\end{tabular}

* Values less than $1.0 \%$ not shown. i, iso; ai, anteiso.

$\dagger$ Also contained unknown fatty acid $(7 \cdot 8 \%)$ at the retention time between hexadecanoic acid $\left(\mathrm{C}_{16: 0}\right)$ and 15 -methylhexadecenoic acid $\left(\mathrm{i}-\mathrm{C}_{17: 1}\right)$. 
validated species of the genus Amycolatopsis using the combination of fatty acid profiles (Mertz \& Yao, 1993; Yassin et al., 1993; Labeda, 1995; Goodfellow et al., 1997; Chun et al., 1999) and its unique phylogenetic position as well as physiological properties.

On the basis of phenotypic and genotypic data, strain IMSNU 22139 merits being recognized as a novel species in the genus Amycolatopsis, for which the name Amycolatopsis albidoflavus sp. nov. is proposed.

\section{Description of Amycolatopsis albidoflavus sp. nov.}

Amycolatopsis albidoflavus (al.bi.do.fla'vus. L. adj. albidus white; L. adj. flavus yellow; M.L. adj. albidoflavus whitish yellow).

Forms well-developed aerial mycelium and vegetative mycelium. Both of them fragment into rod-shaped elements. The aerial mycelium is white and the vegetative mycelium is yellow. A yellow soluble pigment is produced on rich media. Aerobic, Grampositive, non-acid-fast. Catalase-positive. $\mathrm{H}_{2} \mathrm{~S}$ is produced. Nitrate is reduced to nitrite. Growth occurs between 10 and $37^{\circ} \mathrm{C}$. Growth does not occur at $45^{\circ} \mathrm{C}$. Acid is produced from adonitol, L-arabinose, Dcellobiose, D-galactose, meso-erythritol, D-fructose, glycerol, meso-inositol, D-lactose, D-mannose, sucrose, $\mathrm{D}$-trehalose and D-xylose. No acid is produced from Dglucose, maltose, D-mannitol, D-melezitose, melibiose, methyl $\alpha$-D-glucoside, D-raffinose, L-rhamnose, salicin, L-sorbose, D-sorbitol and D-xylitol. Casein, aesculin, gelatin, hypoxanthine, starch, DL-tyrosine and xanthine are decomposed. Exhibits weak urease activity. Growth occurs on $7 \% \mathrm{NaCl}$. Type IV cell wall (mesodiaminopimelic acid, arabinose and galactose in the cell wall). Muramic acid is in an $\mathrm{N}$-acetyl form. The major menaquinone is MK-9 $\left(\mathrm{H}_{4}\right)$. The phospholipid profiles contain phosphatidylmethylethanolamine and phosphatidylinositol (a phospholipid type PII pattern). Mycolic acids are not present. The predominant fatty acid is iso-branched hexadecanoic acid. Saturated, unsaturated and branched-chain fatty acids are also present. The $\mathrm{G}+\mathrm{C}$ content of the DNA is $68.5 \mathrm{~mol} \%$. Isolated from soil. Originally deposited in the ATCC by Bristol-Myers Co. The type strain is IMSNU $22139^{\mathrm{T}}\left(=\right.$ KCTC $9471^{\mathrm{T}}=$ ATCC $\left.53205^{\mathrm{T}}\right)$.

\section{ACKNOWLEDGEMENTS}

This work was supported by the Brain Korea 21 Project for the School of Biological Sciences, Seoul National University. The authors are indebted to M. H. Kim and W. Y. Lee for the analysis of cellular fatty acids.

\section{REFERENCES}

de Boer, L., Dijkhuizen, L., Grobben, G., Goodfellow, M., Stackebrandt, E., Parlett, J. H., Whitehead, D. \& Witt, D. (1990). Amycolatopsis methanolica sp. nov., a facultatively methylotrophic actinomycete. Int J Syst Bacteriol 40, 194-204.

Brosius, J., Palmer, J. L., Kennedy, J. P. \& Noller, H. F. (1978).
Complete nucleotide sequence of a 16S ribosomal RNA gene from Escherichia coli. Proc Natl Acad Sci US A 75, 4801-4805.

Chun, J., Kim, S. B., Oh, Y. K. \& 7 other authors (1999). Amycolatopsis thermoflava sp. nov., a novel soil actinomycete from Hainan Island, China. Int J Syst Bacteriol 49, 1369-1373.

Felsenstein, J. (1985). Confidence limits on phylogenies: an approach using the bootstrap. Evolution 39, 783-791.

Fitch, W. M. (1972). Toward defining the course of evolution: minimum change for a specific tree topology. Syst Zool 20, 406-416.

Goodfellow, M., Brown, A. B., Cai, J., Chun, J. \& Collins, M. D. (1997). Amycolatopsis japonicum sp. nov., an actinomycete producing (S,S)-N,N'-ethylenediaminedisuccinic acid. Syst Appl Microbiol 20, 78-84.

Gordon, R. E., Barnett, D. A., Handerhan, J. E. \& Pang, C. H.-N. (1997). Nocardia coeliaca, Nocardia autotrophica, and the nocardia strain. Int J Syst Bacteriol 24, 54-63.

Henssen, A., Kothe, H. W. \& Kroppenstedt, R. M. (1987). Transfer of Pseudonocardia azurea and "Pseudonocardia fastidiosa" to the genus Amycolatopsis, with emended species description. Int J Syst Bacteriol 37, 292-295.

Hopwood, D. A., Bibb, M. J., Chater, K. F. \& 7 other authors (1985). Genetic Manipulation of Streptomyces: a Laboratory Manual. Norwich: John Innes Foundation.

Jukes, T. H. \& Cantor, C. R. (1969). Evolution of protein molecules. In Mammalian Protein Metabolism, pp. 21-132. Edited by H. N. Munro. New York: Academic Press.

Kim, S. B. \& Goodfellow, M. (1999). Reclassification of Amycolatopsis rugosa Lechevalier et al. 1986 as Prauserella rugosa gen. nov. comb. nov. Int J Syst Bacteriol 49, 507-512.

Kroppenstedt, R. M. (1985). Fatty acid and menaquinone analysis of actinomycetes and related organisms. In Chemical Methods in Bacterial Systematics, pp. 173-199. Edited by M. Goodfellow \& D. E. Minnikin. London: Academic Press.

Labeda, D. P. (1995). Amycolatopsis coloradensis sp. nov., the avoparcin (LL-AV290)-producing strain. Int J Syst Bacteriol 45, 124-127.

Lechevalier, M. P., De-Bievre, C. \& Lechevalier, H. A. (1977). Chemotaxonomy of aerobic actinomycetes: phospholipid composition. Biochem Syst Ecol 5, 249-260.

Lechevalier, M. P., Prauser, H., Labeda, D. P. \& Ruan, J.-S. (1986). Two new genera of nocardioform actinomycetes: Amycolata gen. nov. and Amycolatopsis gen. nov. Int J Syst Bacteriol 36, 29-37.

Lee, S. D., Kang, S.-O. \& Hah, Y. C. (2000a). Hongia gen. nov., a new genus of the order Actinomycetales. Int $J$ Syst Evol Microbiol 50, 191-199.

Lee, S. D., Kim, E. S. \& Hah, Y. C. (2000b). Phylogenetic analysis of the genera Pseudonocardia and Actinobispora based on the 16S rDNA sequence studies. FEMS Microbiol Lett 182, 125-129.

Lee, S. D., Kim, E. S., Roe, J.-H., Kim, J.-H., Kang, S.-O. \& Hah, Y. C. (2000c). Saccharothrix violacea sp. nov., isolated from a gold mine cave, and Saccharothrix albidocapillata comb. nov. Int $J$ Syst Evol Microbiol 50, 1315-1323.

MacFaddin, J. F. (1980). Biochemical Tests for Identification of Medical Bacteria, 2nd edn. Baltimore: Williams \& Wilkins.

Mertz, F. P. \& Yao, R. C. (1993). Amycolatopsis alba sp. nov., isolated from soil. Int $J$ Syst Bacteriol 43, 715-720.

Mesbah, M., Premachandran, U. \& Whitman, W. B. (1989). Precise measurement of the $\mathrm{G}+\mathrm{C}$ content of deoxyribonucleic acid by 
high-performance liquid chromatography. Int $J$ Syst Bacteriol 39, 159-167.

Minnikin, D. E. M. (1988). Isolation and purification of mycobacterial wall lipids. In Bacterial Cell Surface Techniques, pp. 125-135. Edited by I. C. Hancock \& I. R. Poxton. Chichester: Wiley.

Minnikin, D. E., Alshamaony, L. \& Goodfellow, M. (1977). Differentiation of Mycobacterium, Nocardia, and related taxa by thin layer chromatographic analysis of whole-cell methanolysates. J Gen Microbiol 88, 200-204.

Minnikin, D. E., Hutchinson, I. G., Caldicott, A. B. \& Goodfellow, M. (1980). Thin layer chromatography of methanolysates of mycolic acid-containing bacteria. J Chromatogr 188, 221-233.

Minnikin, D. E., O'Donnell, A. G., Goodfellow, M., Alderson, G., Athalye, M., Schaal, A. \& Parlett, J. H. (1984). An integrated procedure for the extraction of bacterial isoprenoid quinones and polar lipids. J Microbiol Methods 2, 233-241.

Saddler, G. S., Tavecchia, P., Lociuro, S., Zanol, M., Colombo, E. \& Selva, E. (1991). Analysis of madurose and other actinomycete whole cell sugars by gas chromatography. J Microbiol Methods 14, 185-191.

Saitou, N. \& Nei, M. (1987). The neighbor-joining method: a new method for reconstructing phylogenetic trees. Mol Biol Evol 4, 406-425.
Staneck, J. L. \& Roberts, G. D. (1974). Simplified approach to identification of aerobic actinomycetes by thin-layer chromatography. Appl Microbiol 28, 226-231.

Swofford, D. (1998) PAUP*: phylogenetic analysis using parsimony (* and other methods), version 4.0. Sinauer Associates, Sunderland, MA, USA.

Thompson, J. D., Higgins, D. G. \& Gibson, T. J. (1994). CLUSTAL $\mathrm{W}$ : improving the sensitivity of progressive multiple sequence alignment through sequence weighing, position-specific gap penalties and weight matrix choice. Nucleic Acids Res 22, 4673-4680.

Uchida, K. \& Aida, K. (1984). An improved method for the glycolate test for simple identification of the acyl type of bacterial cell walls. J Gen Appl Microbiol 30, 131-134.

Warwick, S., Bowen, T., McVeigh, H. P. \& Embley, T. M. (1994). A phylogenetic analysis of the family Pseudonocardiaceae and the genera Actinokineospora and Saccharothrix with 16S rRNA sequences and a proposal to combine the genera Amycolata and Pseudonocardia in an emended genus Pseudonocardia. Int J Syst Bacteriol 44, 293-299.

Yassin, A. F., Haggenei, B., Budzikiewicz, H. \& Schaal, K. P. (1993). Fatty acid and polar lipid composition of the genus Amycolatopsis: application of fast bombardment-mass spectrometry to the structure analysis of underivatized phospholipids. Int J Syst Bacteriol 43, 414-420. 